\title{
KEMAMPUAN MENGAJUKAN MASALAH DIRELASIKAN DENGAN KEMAMPUAN BERPIKIR LOGIS MATEMATIK
}

\author{
The Ability of Problem Posing Related With Logical Thinking \\ MATHEMATICAL ABILITY
}

Nitta Puspitasari

Program Studi Pendidikan Matematika, Institut Pendidikan Indonesia

Jl. Pahlawan No. 32 Sukagalih, Garut, Jawa Barat, Indonesia

puspita6881@gmail.com

\begin{abstract}
Abstrak
Kajian ini memaparkan tentang kemampuan mengajukan masalah matematis direlasikan dengan kemampuan berpikir logis matematis. Kemampuan mengajukan masalah serta berpikir matematis merupakan kemampuan esensial yang dimiliki dan dikembangkan oleh siswa untuk bisa menghadapi kemajuan IPTEK yang semakin pesat. Karena kedua kemampuan tersebut menjadi hal yang penting, maka diperlukan panduan pengembangan kemampuan tersebut jika dikaitkan satu dengan yang lainnya. Pada kajian ini juga menyajikan bagaimana rubrik penilaian mengajukan masalah direlasikan dengan kemampuan berpikir logis. Hal ini diharapkan dapat menjadi stimulus untuk mengembangkan kemampuan mengajukan masalah matematis secara optimal.

Kata Kunci: mengajukan masalah, berpikir logis.
\end{abstract}

\begin{abstract}
This study presents a mathematical problem posing ability related to the ability to logical thinking mathematically. The ability mathematical problem posing and logical thinking is an essential capability owned and developed by students to deal with advances in science and technology that rapidly. Since both the ability it becomes important, then needed the capability development guidance if it is associated with the other. In this study also present how the rubric assessment mathematical problem posing to related with the ability logical thinking. It is expected to be a stimulus to develop mathematical problem posing capability optimally.

Keyword: Mathematical problem posing, logical thinking.
\end{abstract}




\section{Pendahuluan}

Pada dasarnya, kemampuan mengajukan masalah serta berpikir logis matematik adalah dua kemampuan esensial yang perlu dimiliki oleh dan dikembangkan pada siswa yang belajar matematika. Secara lebih rinci, tujuan pembelajaran matematika (KTSP, 2006, Kurikulum Matematika, 2013) diantaranya menggunakan penalaran berdasarkan pola dan sifat, melakukan manipulasi matematika dalam membuat generalisasi, menyusun bukti, atau menjelaskan gagasan dan pernyataan matematika, dan memiliki sikap menghargai kegunaan matematika dalam kehidupan, sikap rasa ingin tahu, perhatian, dan minat dalam mempelajari matematika, serta sikap ulet dan percaya diri dalam pemecahan masalah. Demikian pula, Romberg (NCTM, 2009) tujuan pembelajaran matematika diantaranya: belajar bernalar secara matematis yaitu membuat konjektur, bukti, dan membangun argumen secara matematis serta belajar tentang nilai-nilai matematika, memahami peranan matematika dalam masyarakat serta sains, percaya diri pada kemampuan dan berpikir matematis yang dimiliki, dan peka terhadap situasi dan masalah.

Beberapa studi melaporkan bahwa KBLM merupakan tugas matematik yang tergolong sulit bagi siswa sekolah menengah atas (SMA) bahkan juga untuk sebagian mahasiswa (Wason dalam Markovits \& Barrouillet, 2004). Demikian pula beberapa studi melaporkan temuan yang serupa yaitu KBLM siswa tergolong antara kurang dan sedang (Rohaeti, Budiyanto, Sumarmo, 2013, Setiawati, 2014, Sumarmo, 1987, Sumarmo, Hidayat, Zulkarnaen, Hamidah, Sariningsih, 2012).

Berkenaan dengan KMMM beberapa studi melaporkan temuan yang beragam. Hendriana (2002) dengan menerapkan pembelajaran berbalik (reciprocal teaching). melaporkan pencapaian dan peningkatan KMMM siswa sebelum, selama, dan sesudah pemecahan masalah matematik yang mendapat pembelajaran terbalik lebih baik dari KMMM siswa yang mendapat pembelajaran konvensional. Selain itu, Singer, Ellerton, dan Cai (2013) mengupas temuan beberapa studi berkenaan dengan KMMM, di antaranya: a) Masalah yang diajukan siswa memajukan kreativitas siswa (Silver, 1997; Yuan dan Sriraman, 2011, dalam Singer, Ellerton, dan Cai, 2013); b) Kegiatan mengajukan masalah matematik memberikan pengaruh positif terhadap belajar siswa (Cai dan Hwang, 2002, dalam Singer, Ellerton, dan Cai, 2013); c) Kemampuan mengajukan masalah yang kompleks mendukung tumbuhnya kemampuan memecahkan masalah (Cai dan Hwang, 2002, dalam Singer, Ellerton, dan Cai, 2013); d) Mahasiswa cenderung lebih suka menyelesaikan masalah matematik dari pada mengajukan masalah matematik, tugas menyusun MPP merupakan pengalaman pertama bagi mahasiswa; e) Tugas MMM membantu memahami konsep matematika, dan merupakan tugas yang menantang (Elerton, 2013). 


\section{KAJIAN TEORI}

\section{A. Berpikir Logis Matematik}

Dalam beberapa pembahasan istilah berpikir logis (logical thinking) sering kali dipertukarkan dengan istilah bernalar logis (logical reasoning), karena keduanya memuat beberapa kegiatan yang serupa. Sesungguhnya, istilah berpikir logis (logical thinking) mempunyai cakupan yang lebih luas dari bernalar logis (logical reasoning). Istilah penalaran logis memuat kegiatan menjelaskan mengapa dan bagaimana suatu hasil diperoleh atau mengapa dan bagaimana cara menarik kesimpulan dari premis yang tersedia, atau sebagai penarikan kesimpulan beradasarkan aturan inferensi. Sedangkan istilah berpikir logis memuat kegiatan yang lebih luas antara lain menyelesaikan masalah matematik secara rasional atau masuk akal. Capie dan Tobin (1980, dalam Sumarmo, 1987) mengukur kemampuan berpikir logis berdasarkan teori perkembangan mental dari Piaget melalui Test of Logical Thinking (TOLT) yang terdiri dari 10 butir tes meliputi lima komponen yaitu: mengontrol variabel (controling variable), penalaran proporsional (proportional reasoning), penalaran probabilistik (probalistics reasoning), penalaran korelasional (correlational reasoning), dan penalaran kombinatorik (combinatorial reasoning). Peneliti lain Sheehan (Mc Donald dan Sheehan, 1983 dalam Sumarmo, 1987) mengukur kemampuan berpikir logis melalui tes Longeot yang terdiri dari 26 butir tes yang meliputi komponen logis formal (formal logic of propositions), kombinasi formal (formal combinations), dan proporsi formal (formal proportions).

Merujuk pada pendapat sejumlah pakar (Albrecht, 1984, Capie and Tobin, 1981, dalam Sumarmo, 1987, Soekadijo, 2003, Strydom, dalam Aminah, 2011, Suryasumantri, 1996), Sumarmo (2010) mengajukan dua jenis utama penalaran matematik yaitu penalaran induktif dan penalaran deduktif matematik. Penalaran induktif matematik meliputi: a) Analogi yaitu menarik kesimpulan berdasarkan keserupaan proses atau konten; Generalisasi yaitu menarik konklusi umum berdasarkan data terbatas; c) Merumuskan konjektur berdasarkan data terobservasi atau pernyataan; d) Menyusun estimasi atau perkiraan berdasarkan serangkaian data atau proses. Sedangkan penalaran deduktif matematik meliputi: a) Menyelesaikan perhitungan berdasarkan aturan atau rumus yang disepakati; b) Menarik kesimpulan logis matematik atau berpikir logis matematik (BLM), yang meliputi: menarik kesimpulan berdasarkan proporsi dua atau lebih komponen (penalaran proporsional), menarik kesimpulan berdasarkan aturan inferensi (penalaran proposisional), menarik kesimpulan berdasarkan kombinasi beberapa unsur (penalaran kombinatorial), menarik kesimpulan berdasarkan peluang suatu kejadian (penalaran probalistik); menarik kesimpulan berdasarkan korelasi beberapa elemen (penalaran korelasional); c) Memeriksa validitas argumen matematik; 
d) Menyusun argumen yang valid; e Membuktikan keberanan serangkaian pernyataan: pembuktian langsung, pembuktian tak langsung, dan pembuktian dengan induksi matematik.

\section{B. Kemampuan Mengajukan Masalah Matematik}

Istilah kemampuan mengajukan masalah matematik (KMMM) merupakan terjemahan dari istilah Matematical Problem Posing Ability. Pentingnya pembahasan dan pengembangan mathematical problem posing ability atau kemampuan mengajukan masalah matematika disingkat KMMM dikemukakan oleh beberapa pakar. Dalam MMM terkandung kegiatan menyusun masalah baru, atau mereformulasi masalah semula berdasarkan serangkaian data atau informasi yang disajikan. Ditinjau dari banyaknya kemungkinan respons atau jawab dan kualitasnya, tugas MMM bersifat open-ended yang berarti terdapat beragam respons dan beragam kualitas respons.

Istilah KMMM berhubungan dengan istilah masalah (problem), yaitu suatu kondisi yang penyelesaiannya tidak segera dapat ditemukan. Ditinjau dari segi sifatnya, masalah dapat bersifat tertutup atau disebut masalah tertutup (closed problem), dan masalah dapat bersifat terbuka atau disebut masalah terbuka (opened problem). Suatu masalah dikatakan tertutup bila memiliki satu jawaban dan atau satu cara penyelesaian. Masalah dikatakan terbuka bila memiliki beragam cara penyelesaian dan atau jawaban atau solusi. Ditinjau dari segi susunan komponennya, masalah dapat bersifat terstruktur baik (well structured) dan kurang terstruktur (ill structured).

Berdasarkan uraian tentang pengertian problem posing dari sejumlah pakar, berikut ini dirangkumkan beberapa pengertian MMM sebagai berikut:

a) Problem finding, problem sensing, problem formulating, problematizing

b) Mathematical creative problem discovery, mathematical problem creating

c) Mathematical problem posing (MMM) sebelum, selama, dan sesudah menyelesaikan masalah matematik.

d) Mathematical problem sensing; Mathematical problem envisaging

e) Mathematical problem posing (MMM) yang dikaitkan dengan variabel tugas dan atau variabel subyek

Memperhatikan definisi MMM pada butir e) pada dasarnya MMM dapat dimodifikasi dan dikaitkan kemampuan matematik lainnya, misalnya dengan kemampuan berpikir logis matematik (KBLM). Sebelum kualitas MMM dianalisis lebih rinci berdasarkan dimensi kreatifnya, atau kemampuan matematik lainnya MMM dianalisis dulu kelayakannya melalui struktur masalah yang termuat dalam MMM tersebut seperti tercantum pada Diagram 1 (disarikan dari: Bonotto, 2013, Silver dan Cai, 1996, dan Yuan dan Sriraman, 2010, dalam Rosli, Goldsby dan Capraro, 2013). 


\section{Keterkaitan MMM dengan KBLM}

Sejumlah pakar mengemukakan bahwa KMMM berelasi dengan kemampuan matematik lainnya, misalnya dengan pemahaman konsep matematik dan sikap dan rasa percaya diri dalam belajar matematika (English, 1997 dalam Harpen dan Presmeg, 2013, Silver, 1998 dalam Bonotto, 2013), dengan kemampuan berpikir kreatif matematik (Cai dan Cefarelli, 1994, Jay dan Perkins, 1997 dalam Harpen dan Sriraman, 2013, Silver, 1994, Singer dan Mascovisi, 2008, dalam Bonotto, 2013, Silver, 1997 dalam Harpen dan Presmeg, 2013, Harpen dan Sriraman, 2013, Presmeg, 1986, Torrance, 1988, dalam Xianwei dan Sriraman, 2012), dengan kemampuan berpikir kritis matematik (Bonotto, 2013). Selain itu, Cai (2003), mengemukakan bahwa KMMM adalah salah satu komponen kunci dari eksplorasi matematik. Dalam inkuri, merumuskan suatu masalah dengan baik adalah lebih signifikan dari pada menemukan solusi masalah yang bersangkutan. Oleh karena itu, memusatkan pada cara siswa melakukan MMM membantu menemukan cara berpikir siswa dipandang dari berbagai persepektif.

Setelah diperoleh kualitas MMM yang memadai, untuk memperoleh mengukur kualitas MMM perlu disusun suatu Pedoman Pemberian Skor untuk tiap butir KMMM yang disesuaikan dengan kemampuan matematik tertentu. Mempertimbangkan adanya keterbatasan lama satuan waktu tertentu, berikut ini ditawarkan rubrik pemberian skor butir skala KMMM yang direlasikan dengan KBLM (Sumarmo, 2015b). Rubrik pada Tabel 2 berikut ini dimodifikasi dari Rubrik Pemberian Skor yang disarikan dari Shriki (2013) seperti pada Tabel 1. 


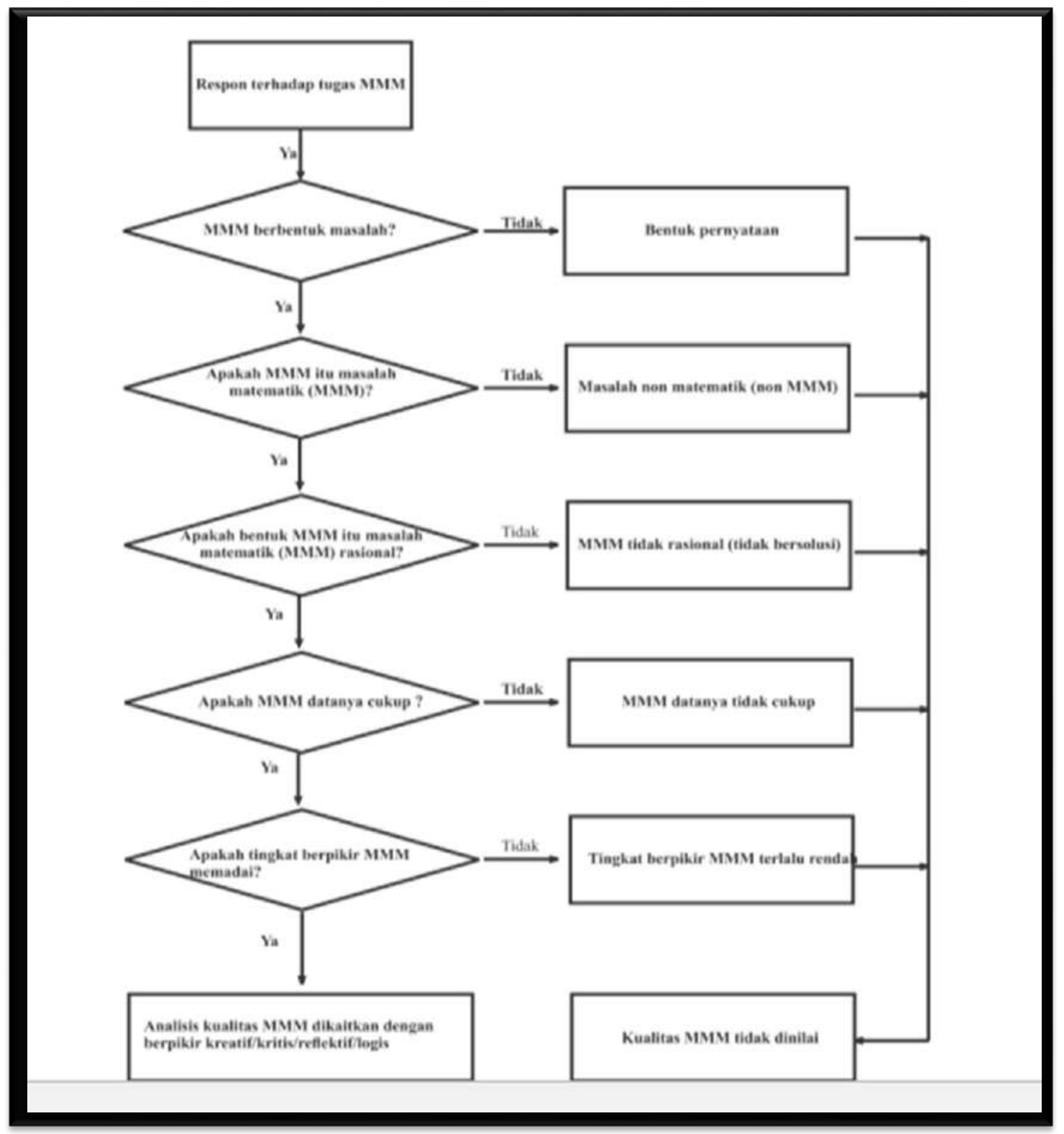

Gambar 1. Analisis kualitas bentuk masalah matematik (MMM).

Tabel 1.

Kriteria Pemberian Skor Dimensi Kreatif MPP.

\begin{tabular}{ll}
\hline \multicolumn{1}{c}{ Dimensi Kreatif } & \multicolumn{1}{c}{ Kriteria Pemberian Skor } \\
\hline Kelancaran & Kelancaran MPP didasarkan pada banyaknya MPP yang diajukan. \\
& Misalnya, siswa A mengajukan MPP paling banyak (m) di antara teman- \\
& temannya. Maka A mendapat skor total kelancaran m dan skor relatif \\
& 100. Siswa lain, B mengajukan MPP sebanyak n. Maka B mendapat skor \\
& total kelancaran n dan skor relatif kelancaran sebesar $\mathrm{n} / \mathrm{m} \times 100$. \\
\hline Keluwesan & Keluwesan MPP didasarkan pada banyaknya MPP berbeda katagori \\
& yang diajukan. Siswa A mengajukan MPP berbeda katagori paling \\
& banyak (misalnya m) di antara teman-temannya. Maka A mendapat \\
\hline
\end{tabular}




\begin{tabular}{|c|c|}
\hline & $\begin{array}{l}\text { skor total keluwesan } \mathrm{m} \text { dan skor relatif keluwesan } 100 \text {. Siswa lain, B } \\
\text { mengajukan MPP berbeda katagori sebanyak } \mathrm{n} \text {. Maka B mendapat skor } \\
\text { total keluwesan } \mathrm{n} \text { dan skor relatif keluwesan sebesar } \mathrm{n} / \mathrm{m} \times 100\end{array}$ \\
\hline Keaslian & $\begin{array}{l}\text { Keaslian MPP ditetapkan bila MPP diajukan oleh kurang sepertiga atau } \\
33 \% \text { seluruh siswa. Siswa A mengajukan paling banyak (misal m) MPP } \\
\text { asli. Maka A mendapat skor total keaslian m dan skor relatif keaslian } \\
\text { 100. Siswa lain, B mengajukan MPP berbeda katagori sebanyak } \mathrm{n} \text {. Maka } \\
\text { B mendapat skor total keaslian } \mathrm{n} \text { dan skor relatif keaslian sebesar n/m } \\
\text { x } 100\end{array}$ \\
\hline Organisasi (Generalisasi) & $\begin{array}{l}\text { Generalisasi MPP ditetapkan bila MPP memuat masalah generalisasi. } \\
\text { Misal siswa A mengajukan MPP generalisasi yang paling banyak (m) di } \\
\text { antara teman-temannya. Jadi A mendapat skor total MPP generalisasi } \\
\text { sebesar } \mathrm{m} \text { dan skor relatifnya } 100 \text {. Siswa B mengajukan } \mathrm{n} \text { MPP } \\
\text { generalisasi. Jadi B mendapat skor total MPP generalisasi dan skor } \\
\text { relatif generalisasi adalah } \mathrm{n} / \mathrm{m} \times 100\end{array}$ \\
\hline
\end{tabular}

(Disajikan dari Shriki, 2013)

Tabel 2.

Contoh Rubrik Pemberian Skor pada Tes KMMM

Dikaitkan dengan KBLM

\begin{tabular}{|c|c|c|c|}
\hline $\begin{array}{l}\text { Dimensi } \\
\text { MMM }\end{array}$ & Dimensi KBLM & Indikator Pemberian Skor & Skor \\
\hline \multirow{5}{*}{$\begin{array}{l}\text { i masalah dari } \\
\text { serangkaian } \\
\text { informasi }\end{array}$} & & Tidak ada respons, respons tidak rasional & 0 \\
\hline & \multirow[t]{2}{*}{$\begin{array}{l}\text { Penalaran } \\
\text { proporsional, }\end{array}$} & $\begin{array}{l}\text { Menyusun } 1 \text { MPP benar, memuat tugas } \\
\text { penalaran proporsional }\end{array}$ & 1 \\
\hline & & $\begin{array}{l}\text { Menyusun } 2 \text { MPP benar memuat tugas } \\
\text { penalaran proporsional }\end{array}$ & 2 \\
\hline & \multirow[t]{2}{*}{$\begin{array}{c}\text { Penalaran } \\
\text { kombinato-rial, }\end{array}$} & $\begin{array}{l}\text { Menyusun } 1 \text { MPP benar memuat tugas } \\
\text { penalaran kombinatorial, }\end{array}$ & 1 \\
\hline & & $\begin{array}{l}\text { Menyusun } 2 \text { MPP benar memuat tugas } \\
\text { penalaran kombinatorial, }\end{array}$ & 2 \\
\hline \multirow{6}{*}{\begin{tabular}{l}
\multicolumn{2}{c}{ Memformulas } \\
i masalah dari \\
serangkaian \\
informasi
\end{tabular}} & \multirow[t]{2}{*}{$\begin{array}{l}\text { Penalaran } \\
\text { probabilistik, }\end{array}$} & $\begin{array}{l}\text { Menyusun } 1 \text { MPP benar memuat tugas } \\
\text { penalaran probabilistik }\end{array}$ & 1 \\
\hline & & $\begin{array}{l}\text { Menyusun } 2 \text { MPP benar memuat tugas } \\
\text { penalaran probabilistik }\end{array}$ & 2 \\
\hline & \multirow{2}{*}{$\begin{array}{l}\text { Penalaran } \\
\text { korelasional/ } \\
\text { Sebab dan } \\
\text { akibat }\end{array}$} & $\begin{array}{l}\text { Menyusun } 1 \mathrm{MPP} \text { benar memuat tugas } \\
\text { penalaran korelasional/sebab dan akibat }\end{array}$ & 1 \\
\hline & & $\begin{array}{l}\text { Menyusun } 2 \text { MPP benar memuat tugas } \\
\text { penalaran korelasional/sebab dan akibat }\end{array}$ & 2 \\
\hline & \multirow[t]{2}{*}{$\begin{array}{r}\text { Penalaran } \\
\text { proposisional }\end{array}$} & $\begin{array}{l}\text { Menyusun } 1 \text { MPP benar, memuat tugas } \\
\text { penalaran proposisional }\end{array}$ & 1 \\
\hline & & $\begin{array}{l}\text { Menyusun } 2 \text { MPP benar, memuat tugas } \\
\text { penalaran proposisional }\end{array}$ & 2 \\
\hline
\end{tabular}




\begin{tabular}{|c|c|c|c|}
\hline Dimensi MMM & Dimensi KBLM & Indikator Pemberian Skor & Skor \\
\hline \multirow{11}{*}{$\begin{array}{l}\text { Mereformulasi } \\
\text { masalah/Meng- } \\
\text { kreasi masalah } \\
\text { baru }\end{array}$} & & Tidak ada respons, respons tidak rasional & 0 \\
\hline & \multirow[t]{2}{*}{$\begin{array}{l}\text { Penalaran } \\
\text { proporsional }\end{array}$} & $\begin{array}{l}\text { Mengkreasi } 1 \text { MPP baru benar, memuat tugas } \\
\text { penalaran proporsional }\end{array}$ & 1 \\
\hline & & $\begin{array}{l}\text { Mengkreasi } 2 \text { MPP baru benar, memuat tugas } \\
\text { penalaran proporsional }\end{array}$ & 2 \\
\hline & \multirow[t]{2}{*}{$\begin{array}{l}\text { Penalaran } \\
\text { kombinatorial }\end{array}$} & $\begin{array}{l}\text { Mengkreasi } 1 \text { MPP baru benar memuat tugas } \\
\text { Penalaran kombinatorial }\end{array}$ & 1 \\
\hline & & $\begin{array}{l}\text { Mengkreasi } 2 \text { MPP baru benar memuat tugas } \\
\text { Penalaran kombinatorial }\end{array}$ & 2 \\
\hline & \multirow[t]{2}{*}{$\begin{array}{l}\text { Penalaran } \\
\text { probabilistik, }\end{array}$} & $\begin{array}{l}\text { Mengkreasi } 1 \text { MPP baru benar, memuat tugas } \\
\text { penalaran probabilistik, }\end{array}$ & 1 \\
\hline & & $\begin{array}{l}\text { Mengkreasi } 2 \text { MPP baru benar, memuat tugas } \\
\text { penalaran probabilistik, }\end{array}$ & 2 \\
\hline & \multirow{2}{*}{$\begin{array}{l}\text { Penalaran } \\
\text { korelasional/ } \\
\text { Sebab dan akibat }\end{array}$} & $\begin{array}{l}\text { Mengkreasi } 1 \text { MPP baru benar, memuat tugas } \\
\text { penalaran korelasional/ }\end{array}$ & 1 \\
\hline & & $\begin{array}{l}\text { Mengkreasi } 2 \text { MPP baru benar, memuat tugas } \\
\text { penalaran korelasional/ }\end{array}$ & 2 \\
\hline & \multirow[t]{2}{*}{$\begin{array}{l}\text { Penalaran } \\
\text { proposisional }\end{array}$} & $\begin{array}{l}\text { Mengkreasi } 1 \text { MPP baru benar memuat tugas } \\
\text { Penalaran proposisional }\end{array}$ & 1 \\
\hline & & $\begin{array}{l}\text { Mengkreasi } 2 \text { MPP baru benar memuat tugas } \\
\text { Penalaran proposisional }\end{array}$ & 2 \\
\hline Dimensi MMM & Dimensi KBLM & Indikator Pemberian Skor & Skor \\
\hline \multirow{5}{*}{$\begin{array}{l}\text { Merinci masalah } \\
\text { utama ke dlm } \\
\text { masalah } \\
\text { bagiannya }\end{array}$} & & Tidak ada respons, respons tidak rasional & 0 \\
\hline & \multirow[t]{2}{*}{$\begin{array}{l}\text { Penalaran } \\
\text { proporsional }\end{array}$} & $\begin{array}{l}\text { Merinci } 1 \text { MMM utama ke dlm masalah bagiannya } \\
\text { benar memuat tugas Penalaran proporsional }\end{array}$ & 1 \\
\hline & & $\begin{array}{l}\text { Merinci } 2 \text { MMM utama ke dlm masalah bagiannya } \\
\text { benar memuat tugas Penalaran proporsional }\end{array}$ & 2 \\
\hline & \multirow[t]{2}{*}{$\begin{array}{l}\text { Penalaran } \\
\text { kombinatorial }\end{array}$} & $\begin{array}{l}\text { Merinci } 1 \text { MMM utama ke dlm masalah bagiannya } \\
\text { benar memuat tugas Penalaran kombinatorial }\end{array}$ & 1 \\
\hline & & $\begin{array}{l}\text { Merinci } 2 \text { MMM utama ke dlm masalah bagiannya } \\
\text { benar memuat tugas Penalaran kombinatorial }\end{array}$ & 2 \\
\hline \multirow{4}{*}{$\begin{array}{l}\text { Merinci masalah } \\
\text { utama ke dlm } \\
\text { masalah } \\
\text { bagiannya }\end{array}$} & \multirow[t]{2}{*}{$\begin{array}{l}\text { Penalaran } \\
\text { probabilistik, }\end{array}$} & $\begin{array}{l}\text { Merinci } 1 \text { MMM utama ke dlm masalah bagiannya } \\
\text { benar memuat tugas Penalaran probabilistik, }\end{array}$ & 1 \\
\hline & & $\begin{array}{l}\text { Merinci } 2 \text { MMM utama ke dlm masalah bagiannya } \\
\text { benar memuat tugas Penalaran probabilistik, }\end{array}$ & 2 \\
\hline & \multirow{2}{*}{$\begin{array}{l}\text { Penalaran } \\
\text { korelasional/ } \\
\text { Sebab dan akibat }\end{array}$} & $\begin{array}{l}\text { Merinci } 1 \text { MMM utama ke dlm masalah bagiannya } \\
\text { benar memuat tugas Penalaran korelasional }\end{array}$ & 1 \\
\hline & & $\begin{array}{l}\text { Merinci } 2 \text { MMM utama ke dlm masalah bagiannya } \\
\text { benar memuat tugas Penalaran korelasional }\end{array}$ & 2 \\
\hline \multirow[t]{2}{*}{ Dimensi MMM } & Dimensi KBLM & Indikator Pemberian Skor & Skor \\
\hline & $\begin{array}{l}\text { Penalaran } \\
\text { proposisional }\end{array}$ & $\begin{array}{l}\text { Merinci } 1 \text { MMM utama ke dlm masalah bagiannya } \\
\text { benar memuat tugas Penalaran proposisional }\end{array}$ & 1 \\
\hline
\end{tabular}




\begin{tabular}{|c|c|c|c|}
\hline & & $\begin{array}{l}\text { Merinci } 2 \text { MMM utama ke dlm masalah bagiannya } \\
\text { benar memuat tugas Penalaran roposisional }\end{array}$ & 2 \\
\hline \multirow[b]{2}{*}{$\begin{array}{l}\text { Menyusun } \\
\text { masalah } \\
\text { sebelum, selama, } \\
\text { dan sesudah } \\
\text { penyelesaian } \\
\text { masalah }\end{array}$} & \multirow{2}{*}{$\begin{array}{l}\text { Penalaran } \\
\text { proporsional }\end{array}$} & Tidak ada respons, respons tidak rasional & 0 \\
\hline & & $\begin{array}{l}\text { Menyusun } 1 \text { MPP benar sebelum, selama, sesudah } \\
\text { penyelesaian masalah, memuat tugas Penalaran } \\
\text { proporsional, }\end{array}$ & $0-3$ \\
\hline \multirow{4}{*}{$\begin{array}{l}\text { Menyusun } \\
\text { masalah sebelum, } \\
\text { selama, dan } \\
\text { sesudah } \\
\text { penyelesaian } \\
\text { masalah }\end{array}$} & & $\begin{array}{l}\text { Menyusun } 2 \text { MPP benar sebelum, selama, sesudah } \\
\text { penyelesaian masalah, memuat tugas Penalaran } \\
\text { proporsional, }\end{array}$ & $0-6$ \\
\hline & \multirow[t]{2}{*}{$\begin{array}{l}\text { Penalaran } \\
\text { kombinatorial }\end{array}$} & $\begin{array}{l}\text { Menyusun } 1 \text { MPP benar sebelum, selama, sesudah } \\
\text { penyelesaian masalah, memuat tugas Penalaran } \\
\text { kombinatorial }\end{array}$ & $0-3$ \\
\hline & & $\begin{array}{l}\text { Menyusun } 2 \text { MPP benar sebelum, selama, sesudah } \\
\text { penyelesaian masalah, memuat tugas Penalaran } \\
\text { kombinatorial }\end{array}$ & $0-6$ \\
\hline & $\begin{array}{l}\text { Penalaran } \\
\text { probabilistik, }\end{array}$ & $\begin{array}{l}\text { Menyusun } 1 \text { MPP benar sebelum, selama, sesudah } \\
\text { penyelesaian masalah, memuat tugas Penalaran } \\
\text { probabilistik, }\end{array}$ & $0-3$ \\
\hline
\end{tabular}

\begin{tabular}{|c|c|c|c|}
\hline Dimensi MMM & Dimensi KBLM & Indikator Pemberian Skor & Skor \\
\hline & & $\begin{array}{l}\text { Menyusun } 2 \text { MPP benar sebelum, selama, sesudah } \\
\text { penyelesaian masalah, memuat tugas Penalaran } \\
\text { probabilistik, }\end{array}$ & $0-6$ \\
\hline & \multirow[t]{2}{*}{$\begin{array}{l}\text { Penalaran } \\
\text { korelasional/ } \\
\text { Sebab dan akibat }\end{array}$} & $\begin{array}{l}\text { Menyusun } 1 \text { MPP benar sebelum, selama, sesudah } \\
\text { penyelesaian masalah, memuat tugas Penalaran } \\
\text { korelasional/ }\end{array}$ & $0-3$ \\
\hline & & $\begin{array}{l}\text { Menyusun } 2 \text { MPP benar sebelum, selama, sesudah } \\
\text { penyelesaian masalah, memuat tugas Penalaran } \\
\text { korelasional/ }\end{array}$ & $0-6$ \\
\hline & \multirow[t]{2}{*}{$\begin{array}{l}\text { Penalaran } \\
\text { proposisional }\end{array}$} & $\begin{array}{l}\text { Menyusun } 1 \text { MPP benar sebelum, selama, sesudah } \\
\text { penyelesaian masalah, memuat tugas Penalaran } \\
\text { proposisional }\end{array}$ & $0-3$ \\
\hline & & $\begin{array}{l}\text { Menyusun } 2 \text { MPP benar sebelum, selama, sesudah } \\
\text { penyelesaian masalah, memuat tugas Penalaran } \\
\text { proposisional }\end{array}$ & $0-6$ \\
\hline
\end{tabular}

\section{Penutup}

Banyak penelitian telah dilakukan untuk mengembangkan kemampuan mengajukan masalah yang dikaitkan dengan kemampuan matematis yang lain.
Oleh karena itu perlu juga dikembangkan kemampuan mengajukan masalah dengan dimensi berpikir logis matematik di berbagai jenjang pendidikan. Hal ini menjadi sangat penting untuk dilakukan untuk melihat seberapa besar asosiasi 
antara kedua kemampuan tersebut. Hasil dari kajian ini diharapkan dapat menjadi stimulus untuk mengembangkan kemampuan mengajukan masalah matematis secara optimal.

\section{Daftar Pustaka}

Aminah, M. (2011). Mengembangkan Kemampuan Berpikir Logis Matematis melalui Pembelajaran Metakognitif. Paper presented in a dicussion at Post Graduate Study of Indonesia University of Education. Unpublished

Albrecth, K. (1984). Brain Building. New Jersey: Prentice-Hall, Inc., 1984.

Bonotto, C. (2013). "Artifacts as sources for problem-posing activities". Educational Studies in Mathematics (2013) 83:37-55. DOI 10.1007/s10649-012-9441-7

Cai, J. (2002). "Singaporean students' mathematical thinking in problem solving and problem posing: an exploratory study" International Journal of Mathematical Education in Science and Technology. 2003. Vol.34. No.5. 719 $-717$. http://www.tandfonline.com/loi/tmes $\underline{20}$

Ellerton, N.F. (2013) “Engaging pre-service middle-school teacher-education students in mathematical problem posing: development of an active learning framework"Educational Studies in Mathematics (2013) 83:87101. DOI 10.1007/s10649-012-9449-z

Ellerton, N. F., \& Clarkson, P. C. (1996). Language factors in mathematics teaching. In A. J. Bishop, K.Clements, C. Keitel, J. Kilpatrick, \& C. Laborde (Eds.), International handbook of mathematics education (pp. 9871053). Netherlands: Kluwer.

Hendriana, H. (2002). Meningkatkan Kemampuan Pengajuan dan Pemecahan Masalah Matematika dengan Pembelajaran Berbalik. (Eksperimen pada siswa kelas I SMUN di Bandung). Tesis pada Program Pascasarjana UPI. Tidak dipublikasi.

Hendriana, H. dan Sumarmo, U. (2013). Penilaian Pembelajaran Matematika. PT Refika Aditama. Bandung.

Leung, Shuk-kwan S. (2013). "Teachers implementing mathematical problem posing in the classroom: challenges and strategies" Educational Studies in Mathematics (2013) 83:103-116. DOI 10.1007/s10649-012-9436-4

Markovits, H.; Barrouillet, P. (2004 )"Introduction: Why Is Understanding The Development Of Reasoning Important?" In Evans, J. B. T; Griggs, R.; Harvey, N.; Over, D. (Eds.) Thinking And Reasoning.Special Issue Development And Reasoning. Psychology Press: Taylor \& Francis Group, 2004, P. 113-121.

NCTM [National Council of Teacher of Mathematics](2009). Principles and Standrads for School Mathematucs. Reston Verginia: NCTM.INC

Permendiknas. Peraturan Menteri Pendidikan Nasional Nomor 23 Tahun 2006 Tentang Standar Isi Dan Standar Kompetensi Lulusan Pendidikan Dasar 
Dan Menengah. Jakarta: Depdiknas, 2006.

Rohaeti, E.E. Budiyanto, A.M., Sumarmo, U. (2014). 'Enhancing Students' Mathematical Logical Thinking Ability and Self Regulated Learning Trough Problem Based Learning". International Journal of Education Vol.8, No. 1. Desember 2014. pp 5463. Graduate School, Indonesia University of Education.

Shriki, A. (2013). "A Model for Assessing the Development of Students' Creativity in the Context of Problem Posing". Creative Education, Vol.4, No.7, 430-439, 2013.

Silver, E.A (2013). "Problem-posing research inmathematics education: looking back, looking around, and looking ahead". Educational Studies in Mathematics. (2013) 83:157-162

Singer, F.M., Ellerton, N., Cai. J. (2013). "Problem-posing research in mathematics education: new questions and directions" Educational Studies in Mathematics (2013) 83:1-7. DOI 10.1007/s10649-013-9478-2

Singer, F.M and Voica, C. (2013) "A problem-solving conceptual framework and its implications in designing problem-posing tasks". Educational Studies in Mathematics. 2013. 83:9-26, DOI 10.1007/s10649012-9422-x

Sumarmo, U. (1987). "Kemampuan Pemahaman Dan Penalaran Matematik Siswa Sma Dikaitkan Dengan Kemampuan Penalaran Logik
Siswa Dan Beberapa Unsur Proses Belajar Mengajar." Dissertation In Post Graduate Study, Institut Keguruan Dan Ilmu Pendidikan Bandung. Un published.

Sumarmo, U. (2005). Pengembangan Berpikir Matematik Tingkat Tinggi Siswa SLTP dan SMU serta Mahasiswa Strata Satu melalui Berbagai Pendekatan Pembelajaran. Laporan tahun pertama Hibah Bersaing Pascasarjana UPI.

Sumarmo, U. (2010). "Berpikir dan Disposisi Matematik: Apa, Mengapa, dan Bagaimana Dikembangkan pada Peserta Didik". Published in Suryadi, D, Turmudi, Nurlaelah, E. (Eds). Kumpulan Makalah Proses Berpikir dan Disposisi Matematik dan Pembelajarannya. 2014. Pp.. 75-89. Jurusan Pendidikan Matematika FPMIPA UPI.

Sumarmo, U. Hidayat, W, Zulkarnaen, R, Hamidah, Sariningsih, R (2012). "Mengembangkan Kemampuan dan Disposisi Berpikir Logis, Kritis, dan Kreatif Siswa SMA melalui Pembelajaran Berbasis Masalah dan Strategi Think-Talk-Write" . Jurnal Pengajaran MIPA, Vol. 17, No.1, 1733, April 2012

Sumarmo, U. (2015a). "Pedoman Pemberian Skor pada Butir Tes Kemampuan Matematik".Makalah dimuat dalam utari-sumarmo@ dosen.stkipsiliwangi. ac.id

Sumarmo, U. (2015 b). "Pengembangan Dan Contoh Butir Skala Nilai, Karakter, 
Budaya Dan Aspek Afektif Lain Dalam

Pembelajaran Matematika". Makalah

dimuat dalam utari-

sumarmo@dosen.stkipsiliwangi.ac,id

Suryasumantri, J. S. (1996). Filsafat IImu.

Sebuah Pengantar Populer. Jakarta:

Pustaka Sinar Harapan,

Tobin, K. G.; Capie, W. (1981). The

development and validation of a

group test of logical thinking. In

Educational and Psychological

Measurement. 1981, 41, p. 413-423.

Available at: <https://www.

researchgate.net/publication/

$\underline{247726847}$

the Development_and_Validation_of

_a_Group_Test_of__ Logical_

Thinking>. Access in: 4 April 2011.

\section{Riwayat Hidup Penulis}

\section{Nitta Puspitasari, S.Pd. M.Pd.}

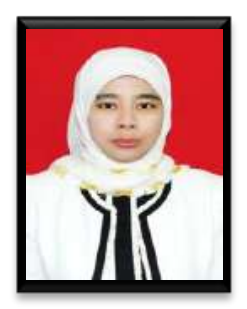

Staf pengajar di Institut Pendidikan Indonesia, Garut. S1 pada program studi Pendidikan Matematika STKIP Garut, lulus tahun 2004. S2 pada program studi Pendidikan Matematika Universitas Pendidikan Bandung, lulus tahun 2010. S3 pada program studi Pendidikan Matematika Universitas Pendidikan Bandung. 